Preprint: Tapsuwan, S., Polyakov, M., Bark, R., \& Nolan, M. (2015). Valuing the BarmahMillewa Forest and in stream river flows: A spatial heteroskedasticity and autocorrelation consistent (SHAC) approach. Ecological Economics, 110, 98-105. DOI:

10.1016/j.ecolecon.2014.12.008

\title{
Valuing the Barmah-Millewa Forest and in stream river flows: A spatial heteroskedasticity and autocorrelation consistent (SHAC) approach
}

Sorada Tapsuwan, Maksym Polyakov, R. Bark, M. Nolan

\begin{abstract}
This paper uses spatial heteroskedasticity and autocorrelation consistent (SHAC) hedonic property price analysis of house sales during 2000-2011 to estimate the marginal value of in stream flows and proximity to an iconic freshwater ecosystem, the Barmah-Millewa Forest (BMF) in Australia's MurrayDarling Basin. We establish: (1) that proximity to the BMF is a statistically significant and positive determinant of nearby house prices in Victoria and New South Wales, i.e. for an average property worth $\$ 199,000$ that is $10 \mathrm{~km}$ away from the BMF, moving $1 \mathrm{~km}$ closer will increase sales price by $\$ 2,835$; and (2) a non-linear relationship between in stream flow and sales price which is suggestive of homebuyers preferences for flow that is neither low (i.e. drought flows) nor high (i.e. flood flows). The results provide estimates of the benefits of in stream flow that could be used to inform freshwater ecosystem restoration policy in the basin and are suggestive of regional benefits that accrue to homeowners living near key freshwater-dependent ecosystems in the basin.
\end{abstract}

Keywords: hedonic pricing, water sharing, in stream flows, aesthetic appreciation, conservation area accessibility index 


\section{Introduction}

In a number of over-allocated river basins, where water allocations exceed sustainable limits with resulting ecosystem degradation, water reform aimed to conserve or restore riparian, wetland and estuarine ecosystems is being attempted. However, environmental water provision for maintaining river flows is often a politically contested issue as it adds another complexity to water sharing between different uses (Garrick et al., 2013). For different countries, the approaches used for river restoration vary. For example, in the Colombia River Basin, northwest U.S., water markets are used to recover water for environmental flows (see Wei et al 2012 for a definition), i.e. water rights are bought temporarily or permanently to be allocated to the environment (Garrick et al., 2009). In the Colorado River Basin, southwest U.S., federal and state partnerships and more recently NGO participation has been instrumental in sourcing environmental water flows to wetlands and the delta in the Mexican part of the basin (Garrick and Bark, 2011; Glenn et al., 2013). In Australia's Murray-Darling Basin the federal government has bought water rights and invested in irrigation infrastructure to transfer water to the environment (Bark et al., 2014). The costs of providing for environmental in stream flows are estimated based on the alternative use of water, e.g. its value to the agricultural industry (e.g. Rigby et al., 2010) or to urban areas (e.g. in northern Mexico, Medellín-Azuara et al., 2007). Consideration of the various non-use and use values associated with river restoration (Loomis, 2006) in general, and with restoration of in stream flows specifically, is important information for water resource managers seeking to maximise benefits and minimise trade-offs.

There are multiple benefits to enhancing in stream flows. Pflüger et al. (2010) suggested that river restoration enhances the naturalness, amenity value and aesthetic quality of these water bodies, which in turn increases its ecological, aesthetic and recreational benefits. Other studies have empirically estimated the value of increased flows. For example, Gibbons et al (2014) investigated the hedonic value of different types of natural amenity using a large dataset of house sales in Great Britain. They found evidence that homes near areas with more freshwater, wetland and floodplains, and are closer to rivers confer positive premiums to homeowners. Specifically, a $1 \%$ increase in the share of freshwater, wetland and floodplains increases house prices by $0.36 \%$. This is equivalent to an implicit price of $£ 694$, where the average house price was $£ 194,000$, in $2008 \mathrm{f}$. Additionally, a $1 \mathrm{~km}$ increase in distance to rivers reduces house price by $0.93 \%$ or $£ 1,811$. Mahan et al. (2000) add to these findings by showing (in the U.S.) that the effect of distance to a wetland depends on wetland type, with preferences for linear open wetlands. Bin (2005) extends this work to Portland, Oregon, U.S. and finds evidence that proximity to open wetlands (up to a distance of 5,500 ft, 1 mile, $1.68 \mathrm{~km}$ ) has a positive effect on property values. He also found that proximity to rivers and lakes has a positive effect on 
house prices, e.g. moving from $3,000 \mathrm{ft}$ to $2,000 \mathrm{ft}(0.57$ to 0.38 mile, $0.91 \mathrm{~km}$ to $0.61 \mathrm{~km})$ to the nearest river increases property values by US\$3,720.

In addition to the benefit of proximity to water bodies, there is evidence suggesting that water level and flow also have an effect on property price. Lansford and Jones (1995) in their study in Texas, U.S. found that for an average home that is worth US\$125,000, the sales price will increase by US\$6,800, if lake level three months prior to sale is six feet (1.83 meters) above the average lake level over the three year period. Loomis and Feldman (2003) in their study of Lake Almanor, California, U.S. found that each additional foot $(30 \mathrm{~cm})$ of exposed lake shoreline resulted in property prices dropping by 5\%-6\%, or US\$108-\$119 (in 2003 prices, average house value US\$187,400). Meanwhile, Hanson et al. (2002) using the contingent valuation method estimated homeowners' perceived change in property value due to reservoir level change in Alabama, U.S. Results show that homeowners believed that a permanent one foot $(30 \mathrm{~cm})$ reduction in summer reservoir levels would decrease the value of lake front properties by 4\%-15\%. Butsic and Netusil (2007) and Netusil and Summers (2009) valued the willingness to pay (WTP) for increased flows designed to improve biophysical outcomes, e.g. for increased fish stock, or reduced water pollution loads. Netusil and Summers (2009), for example, found a significant relationship between water flow and the cost (or price) of purchasing and leasing in stream water rights for fisheries in Oregon, U.S.

Restoration of free-flowing rivers has promise to improve all three elements of river restoration suggested by Pflüger et al. (2010): naturalness, amenity value and aesthetic quality. Two hedonic studies in the U.S. investigate the effect of dam removal and thus restoration of free-flowing streams, on nearby house prices. Lewis et al. (2008) in their study in Maine, U.S. find that there is a reduction in the penalty of living near the former dam with its removal. They note that the small penalty in living near a now free-flowing river was unexpected but that it may be confounded with a penalty for homes that are closer to the downtown, where the dams were located. They also find that dam removal influences house prices far from the removal site suggestive of WTP for improved fisheries, water quality and recreation opportunities as a consequence of restoration of free-flowing passage. Investigating this issue further, Provencher et al. (2008) investigate the effect of small dam removal on house prices using three categories of sites in Madison, Wisconsin, U.S., homes nearby: a small dam (6 sites); a small dam removed in the past 2 years ( 4 sites); and a free-flowing stream for 20 years or more (4 sites). In the linear specified model their results show house price premiums for homes with frontage (US\$13,700 more than a property with a recently removed dam or current impoundment, where average price US\$112,247) and also without frontage near free-flowing 
streams. In their exponential model they like Lewis et al (2008) find that a free-flowing river adds US\$13,900 to nearby non-frontage property within $1 / 4$ mile $(0.4 \mathrm{~km})$ of the river. These studies provide evidence that removal of dams does no harm to property values in the short term and increases values in the long run as the river returns to its natural free-flowing state.

In this paper, we applied the spatial hedonic property analysis to value the aesthetic and recreational benefits of proximity to the Barmah-Millewa Forest (BMF), as well as the implicit valuation for in stream flows that are capitalized into nearby property prices. Results from the analysis suggest that homeowners pay premiums to live closer to the BMF. The results also suggest that homeowners have preferences around river flows that correspond with planned changes to in stream flows for the BMF under river restoration policy in the Murray-Darling Basin (see MDBA, 2012). This research fills a gap in the literature through efforts to separate positively valued water-related amenities from negatively valued exposure to flood risk (Daniel et al., 2009) associated with higher river levels (Rambaldi et al., 2013).

\section{The Barmah-Millewa Forest (BMF)}

The BMF covers an area of 70,000 ha and spans across the States of New South Wales and Victoria in Australia (see Figure 1). It is a Ramsar Convention-listed wetland (Ramsar Convention 1971) and is the world's largest single stand of river red gum forest (Murray-Darling Basin Authority, 2004). From an ecological perspective, the BMF has a large carrying capacity of flora and fauna - it supports rare species and species diversity, and is a wetland of international significance (Maunsell et al., 1992; Stewart and Harper, 2002 as cited in (Murray-Darling Basin Commission, 2005). In addition to its high ecological value, the Murray River, which runs through the BMF, is a major tourist attraction, with approximately 100,000 visitor days per year. On average, visitors travel 4.7 hours round trip for a day visit to the BMF (Dyack et al. 2007). The main draw card is the in stream recreation activities such as canoeing, boating, and fishing (Murray-Darling Basin Commission, 2005), as well as bush walking and bird watching along the river. Scenic areas of the lakes are allocated for camping as well as recreation. Dyack et al. (2007) estimated the recreational value of the BMF using the travel cost method (TCM) to be $A \$ 13 M /$ year (based on 25,000 visitor trips per year). An additional contingent behaviour component of the TCM revealed that if visitors were able to gain access to $20 \%$ more of the BMF area, their consumer surplus would increase from $A \$ 529 /$ adult/trip to $A \$ 593 /$ adult/trip. However, reduction in in stream flow due primarily to diversion for irrigation, has led to a reduction in recreational fishing opportunities from reduced number of native fish spawning in the river (King et al. 2007). 


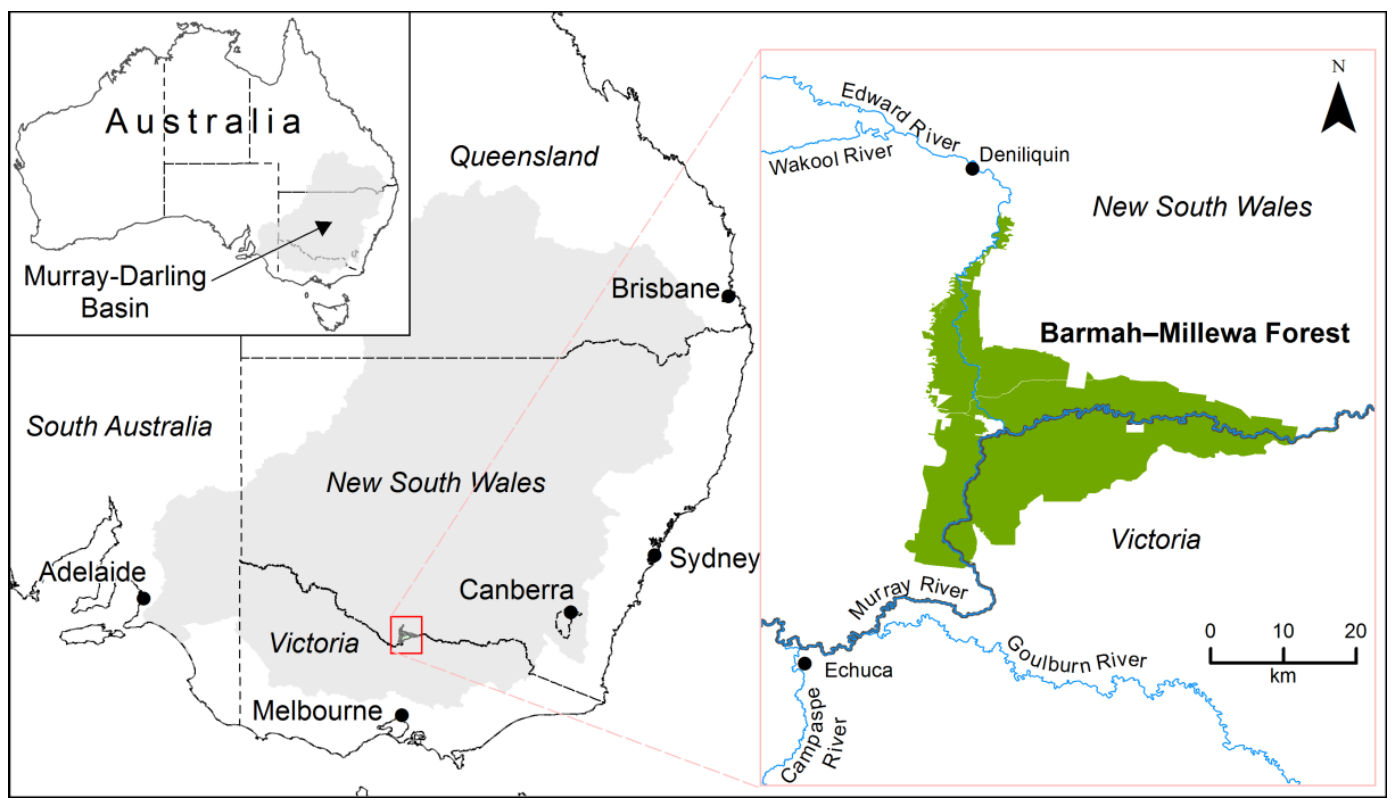

Figure 1 Map of study site showing the Barmah-Millewa Forest, the Murray River and other rivers in the study area.

The BMF provides more than aesthetic and recreational benefits to the region. A number of Australian studies have estimated various benefits of the BMF. For example, Stone (1992) applied the contingent valuation method to ascertain how much people (who lived within $50 \mathrm{~km}$ of the BMF) were willing to donate to save the Barmah wetlands. Using this method Stone (1992) estimated the total value of the Barmah wetlands to be between A\$76.9M and A\$97.5M. Dyack et al. (2007) also estimated the value of the BMF using the contingent valuation method where the authors asked the same respondents of the travel cost survey "If the trip had cost $\$ 50$ more for the group in your vehicle for whatever reason, would you have still decided to come to the Barmah forest?" The bid amount (the cost) varied between $A \$ 10$ and $A \$ 400$. The results estimated the average WTP to visit the BMF to be $A \$ 400 /$ person/visit in addition to their travel costs. Multiplying this number by the estimated number of visitor trips $(25,000 /$ year), the estimated WTP is $A \$ 10 M /$ year, this is in addition to the total travel cost of $A \$ 13 M$, giving a total WTP to visit the BMF of $\$ 23 \mathrm{M} /$ year.

\section{Methodology}

Environmental amenities, such as aesthetic beauty of the forest, or those stemming from in stream flows, are not traded on the market: their values cannot be observed and directly measured. However, their values can be inferred from the observed prices of private goods, such as houses, traded on the 
market, by relating them to housing purchase behaviour. Such inferences can be extended to estimate the expected incremental benefits under, for instance, increased flow or enhanced ecological conditions.

Using the hedonic pricing method developed by Rosen (1974) and expanded to value environmental attributes by Freeman III (1974), the price of the residential property is determined as an interaction of a utility maximized buyer and a profit maximized seller on a housing market. A residential property $i$ can be treated as a multi-attribute good. The price of the property $P_{i}$ is a function of a vector of its attributes $\left(\mathrm{X}_{\mathrm{i}}\right)$. In this analysis, $\mathrm{P}_{\mathrm{i}}$ is the consumer price index (CPI) adjusted selling price (to 2010 value) of property $i$. The vector $X_{i}$ consists of four attribute groups: property structural characteristics $\left(\mathrm{S}_{\mathrm{i}}\right)$, neighbourhood characteristics $\left(\mathrm{N}_{\mathrm{i}}\right)$, environmental characteristics $\left(\mathrm{E}_{\mathrm{i}}\right)$, and time of sales $\left(\mathrm{T}_{\mathrm{i}}\right) . \mathrm{P}_{\mathrm{i}}=$ $f\left(X_{i}\right)$ where $f()$ is a function that describes relationship between the price of the residential property and the values of its attributes. The implicit price of environmental attribute $\mathrm{j}$ can be determined as $\mathrm{p}_{\mathrm{j}}=\partial \mathrm{p}(\mathrm{x}) / \partial \mathrm{x}_{\mathrm{j}}$.

\subsection{Spatial hedonic model specification}

Property sales data as well as location-specific environmental characteristics often exhibit spatial dependency relationships. The presence of spatial dependencies causes bias and inconsistent or inefficient estimates of the marginal implicit prices when the ordinary least squares (OLS) method is used (Anselin, 1988). Additionally, the spatially explicit and cross-sectional property sales data often result in heteroskedasticity and spatial autocorrelation (Boxall et al., 2005). A Breusch-Pagan test is used to test the null hypothesis of homoskedasticity.

Estimating models that account for possible spatial dependencies requires an assumption about the way neighbouring observations influence each other. This is done using a spatial weight matrix, W, that contains weights that quantify the spatial relationship between pairs of observations represented by rows and columns. Among the approaches to construct a spatial weight matrix for data where observations are not immediate neighbours are inclusion into spatial weight matrix of k-nearest neighbours or observations within a specified distance. Another aspect of building a spatial weight matrix is the assumption about weakening spatial relationship with distance. In this case, an inverse distance weight is often used. Spatial weight matrices are usually row-standardized in order to facilitate the interpretation of the coefficients for spatial error or spatial lags models. Currently, there is no consensus among practitioners on the most appropriate type of weight matrix for spatial hedonic 
models, and the challenge of selecting the best matrices has led to ad hoc approaches in practice (Tapsuwan et al., 2012). In this study we adopted a method for constructing a fixed distance spatial weight matrix suggested by Polyakov et al. (2014) with both threshold distance and weight derived from the observed data by analysing a covariogram based on the OLS residuals.

Spatially correlated unobserved variables or measurement errors in variables related to the location of a property cause errors of the model to be spatially correlated. This type of spatial dependence in hedonic models is called spatial error dependence (Anselin, 1988). Another type of spatial dependence, known as spatial lag dependence, occurs when the dependent variable is influenced by the values of dependent variable of the neighbouring observations (Anselin, 1988). For example, the sale price of a property could be affected by the sales prices of the adjacent properties. Although the assumptions of the hedonic pricing method posit that the value of a house is determined by its characteristics, potential buyers often do not have perfect information about the property and neighbourhood characteristics, and rely on prices of recently sold adjacent properties when determining how much they are willing to pay (Maddison, 2009). To check for spatial dependencies, the Moran's / statistic is used to indicate whether there are any spatial dependencies present in the dataset. The Lagrange multiplier test (Anselin and Rey, 1991) is then used to distinguish the type of spatial dependencies - whether the dependency is a spatial error or a spatial lag.

Due to simultaneity in determining spatial lag and spatial error, spatial error and spatial lag models are estimated using maximum likelihood, generalized method of moments, or instrumental variables methods. The models in which the error term showed both spatial autocorrelation and heteroskedasticity require the use of spatial heteroskedasticity and autocorrelation consistent (SHAC) estimators (Kelejian and Prucha, 2010). SHAC estimator is implemented in sphet package in R (Piras, 2010). Estimation of this model requires providing spatial weight matrix, kernel function and a distance bandwidth. In this study, we use fixed distance spatial weight matrix with both threshold distance and weight derived from the OLS residuals, distance bandwidth also derived from the OLS residuals, and a standard Epanechnikov kernel function (Helmers and Patnam, 2014).

\subsection{Data and model specification}

The study uses four data sets in the spatial hedonic analysis: 1) property sales from both Victoria and New South Wales, 2) environmental attributes, 3) in stream flow data and 4) data on tourist infrastructure. Descriptive statistics of the model variables are provided in Table 1. 
The study site covers a rural residential market encapsulating an area that is within $120 \mathrm{~km}$ from the BMF. For Australian standards (i.e. where the population is accustomed to driving long distances for recreation), this distance is within 1.5-2 hours drive, which is sufficiently close for a day trip. Residential properties in this market comprise single family houses in country towns up to large (up to 20 ha) rural residential blocks in nature settings. This property market is famous for lifestyle properties that offer views of the forest and/or the Murray River as well as being in close proximity to forest and river based recreational sites. Property sales data for Victoria were acquired from the Valuer-General's Office of the State of Victoria . Property sales data for the New South Wales were purchased from RP Data ${ }^{\circledR}$, a private company that has an extensive database of property sales information in New South Wales. The data sets acquired from both sources contained information about property sales from year 2000 until year 2011. As these datasets are from different sources the sets of variables are not identical, however, the variables critical to the hedonic property price model e.g. sales price, sales date, number of bedrooms and land area, are available in both data sets. All sales prices were adjusted using the CPI to the 2010 price level (Reserve Bank of Australia, 2011). After removing observations with missing values and outliers, we obtained a dataset with 31,706 observations. A trend variable was included in the model to capture the dynamics of real estate market, beyond inflation. It is a continuous variable that indicates year of sale since January 1, 2001 e.g. the value of trend variable for a property sold on $13 / 04 / 2004$ is 4.28 . A month variable, from January=1 to December=12, was also included to capture the seasonal fluctuations of the property market.

The environmental attributes that were hypothesized to have an impact on sales price, include nature conservation areas, lakes, and rivers. The distance to these areas and their size were all calculated in ArcGIS (ESRI, 2010). For example, the Euclidean distance from the property centroid to the nearest river and lake was calculated using a spatial join operation. To account for effect of conservation areas on property values, we used an index similar to forest access index in Powe et al (1997). We extended this approach to account for the fact that in the study area, conservation areas vary greatly in size and shape. For example, two conservation areas of the same size may vary greatly in shape. One might be relatively compact while the other might be an elongated, for example conservation area along the river. The shape of a conservation area has an impact on how accessible it is. Using a single distance measure from a property to a conservation area, whether it is distance to the nearest edge or a distance to the centre of the conservation area, does not adequately address the issue of conservation area accessibility that is driven by its shape and size. To account for the impact of conservation area shape on accessibility, we overlaid the study area with a regular $1 \mathrm{~km}$ grid and calculated the area of 
conservation areas within each of these grid cells. Some grid cells contain more conservation areas than others, and some contain none. We calculated the conservation area accessibility index (CAAI) for property $i$ as by aggregating distance weighted conservation areas within $60 \mathrm{~km}$ form each property: $C A A I_{i}=\sum_{j} a_{j} / d_{i j} ; \quad d_{i j} \leq 60 \mathrm{~km}$, where $a_{j}$ is the size of the protected area in grid $j$, and $d_{i j}$ is the distance between property $i$ and grid $j$. The greater sum of areas of all conservation areas within $60 \mathrm{~km}$ of the property, and the closer conservation areas are located, the higher is the value of the CAAI.

In addition to proximity and accessibility, the level of landscape greenness, as represented by the average greenness index (normalized difference vegetation index, NDVI) for the 12 months prior to the sale (i.e. if the property was sold in February 2012, then the NDVI variable for that property will be an average NDVI value for the month of March 2011 to February 2012), is also incorporated into the hedonic model. The NDVI captures the qualitative aspects (e.g. greenness) of the landscape on sales price (e.g. see Bark et al., 2011). Additionally, the NDVI variable is a good proxy for seasonal effects on sales price as it is highly correlated with rainfall and temperature. In the earlier versions of the model, we tested the NDVI 3 months, 6 months and 12 months prior to sale, and found that 12 months prior to sale was the best fit for the data. The 12-month time period represents the buyer's overall impression of what the climate is like in general for the locality they are buying into. Elevation, which is commonly found to have significant positive impact on sales price, is also included in the model (see e.g. Mahan et al., 2000 and Tapsuwan et al., 2009 for other studies that have found elevation to be significant).

Daily average in stream flow data for the BMF (1990-2012) was obtained from the Murray-Darling Basin Authority for a gauge station on the Murray River that is within the BMF. The water level in the river is a proxy for measuring in stream flow. For each property sales record, the average daily in stream flow three months prior to sale date was used in the hedonic price models. This time period is typical of the elapsed period between prospective homebuyers searching for a new home and the sales date. Other timeframes, including one month and up to 12 months were also tested for model fit but three months resulted in the best model fit. This choice of the three-month time frame is also consistent with findings from the hedonic study by Lansford and Jones (1995). Flow is hypothesized to have a non-linear effect on price because low flow levels are aesthetically undesirable and excessive flows could lead to floods. In support of this hypothesis, Pflüger et al. (2010) found a concave relationship between aesthetic preference and river flow, where preferences increased with normalized flow up to a threshold of $60 \%$. After the threshold level, aesthetic preference began to 
decline due to increased turbidity. There is also the possibility of in stream flow being affected by seasonal and spatial influences (Olmstead, 2010). For example, the marginal value of flow may decay with distance from the BMF. To account for buyer knowledge or buyer research of the area, a 'flood zone' interaction term was added to the flow variable. It is believed that buyers not only assess flow at time of property inspection, but also consider historical flow records and the possibility of flood risk in the area they want to buy. The flood zone binary variable identifies whether the property is situated in an area that has been flooded before, is $<50 \mathrm{~km}$ away from the flood zone, or is $>50 \mathrm{~km}$ from the flood zone. Approximately $50 \%$ of the sample are situated $>50 \mathrm{~km}$ away from the flood zone. Historical flood record data was obtained from the Murray-Darling Basin Authority website. The data represents the extent of flooding based on historical records and information on flood depth contours and levels (Murray-Darling Basin Authority, 2013).

Accessibility to urban based amenities such as employment, services, and entertainment is important in determining prices of residential properties. A proxy frequently used is to measure distances to the nearest populated places that offer these amenities. However, larger populated places usually offer greater number of such amenities, and such amenities are often offered by multiple populated places of different sizes and in different proximity. To account for both size and proximity effect of populated places that offer urban based amenities, we use a Population Gravity Index (PGI) introduced by Polyakov et al. (2008). The PGI is calculated as the sum of the inverse squared distance weighted population of populated places within a $700 \mathrm{~km}$ radius of the property to account for the influence of, among others, three major metropolitan areas: Sydney, Melbourne and Adelaide. The data on location and population of urban centres and localities were obtained from the website of Australian Bureau of Statistics (www.abs.gov.au).

In another hedonic property price study conducted in South Australia to estimate the marginal benefits of the Murray River and other environmental assets in the region, Tapsuwan et al. (2012) showed that forest parks that have recreational facilities, such as information centres and barbecue areas, offer a higher marginal benefit to nearby properties than parks without recreational facilities. We therefore hypothesize that areas with more tourism and recreational activity are associated with higher property prices. To determine whether the level of tourism has an influence on property price, we included the binary variable indicating whether the nearest town to the property has tourism and recreational facilities, such as a tourist information office. 


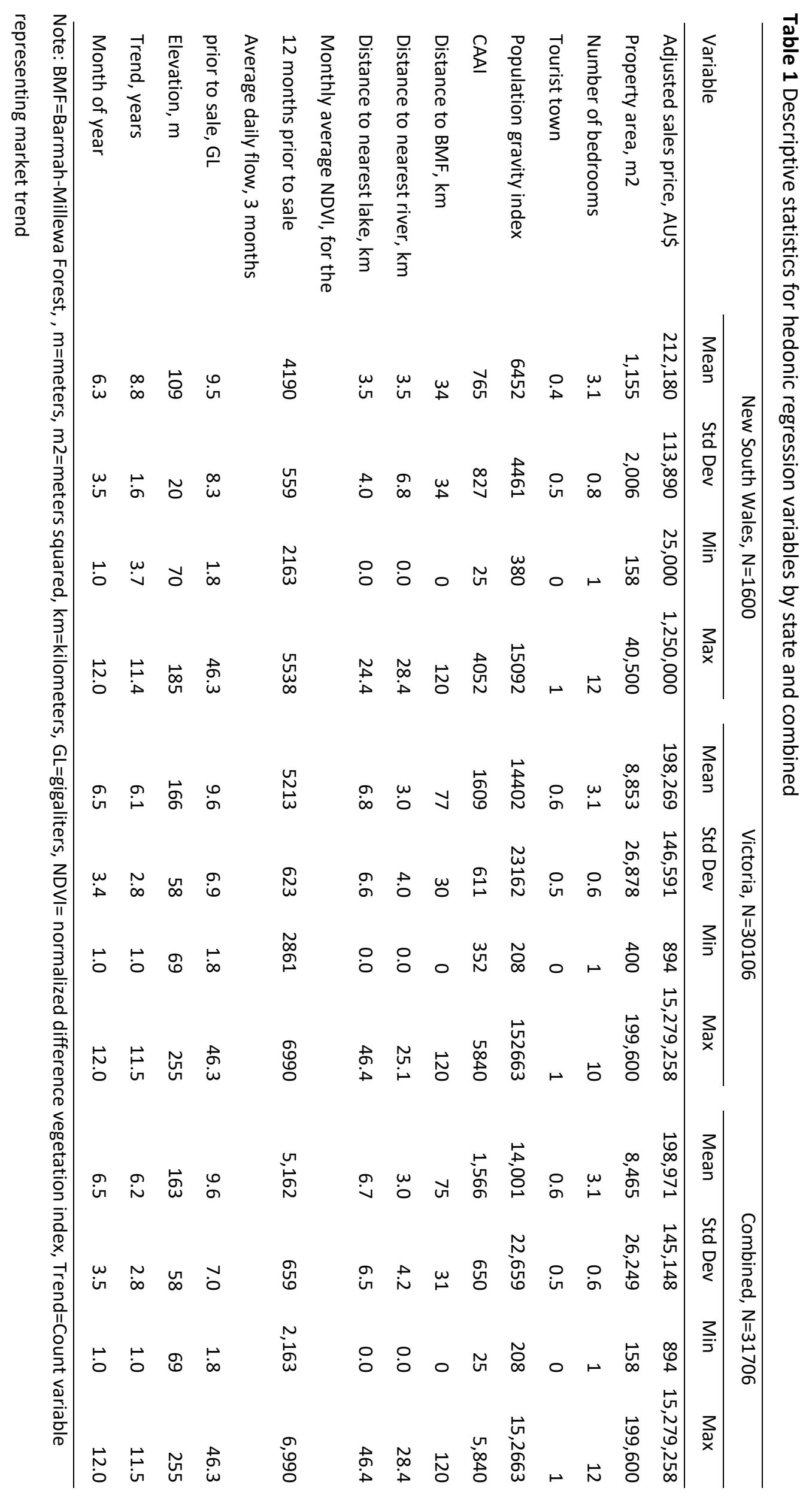


Economic theory offers little guidance on functional form but suggests that the selling price of a property is likely to vary non-linearly with some of the attributes of the house or neighbourhood (Taylor, 2008). To identify the appropriate functional form of the dependent variable in the hedonic model, we used a series of Box-Cox transformations, which suggested that a hedonic model with a natural log transformed dependent variable is an optimal functional form for the data. Regarding functional form of explanatory variables, the hedonic pricing model is often estimated in semi-log, where the natural log of price is the dependent variable with linear independent variables, or in double log form where we take the log of both the dependent and independent variables (Tapsuwan et al. 2009). Rambaldi et al. (2013) argued that the log-linear specification has an advantage in terms of interpretation in that the parameter values can be easily interpreted as the proportional change in the price given a one-unit change in the characteristics. However, in a log-log specification, coefficients are interpreted as elasticities and are constant across the range of values of explanatory variables. The implication of the double log specification for the distance based variables is that, for example, moving $1 \%(100 \mathrm{~m})$ closer to an environmental amenity when a property is $10 \mathrm{~km}$ away would have similar effect as moving $1 \%(10 \mathrm{~km})$ closer if the property is $100 \mathrm{~km}$ away. This is more plausible than the loglinear interpretation where moving $1 \mathrm{~km}$ closer to the environmental amenity when the house is 10 $\mathrm{km}$ away would impact property value by same amount as moving $1 \mathrm{~km}$ closer when the property is $100 \mathrm{~km}$ away. The use of double-log specification for distance based variables is supported by previous hedonic studies (Mahan et al., 2000; Pandit et al., 2013) and therefore, we select double-log specification for distance based variables and semi-log specification for all other variables.

\section{Results}

Results from the OLS estimation of the hedonic model of housing prices can be found in Table 2. The model explains $41 \%$ of the variation of the property value. A Breusch-Pagan test rejects the null hypothesis of homoskedasticity in the model at a $1 \%$ significance level (Table 2 ). 
Table 2 Regression results for the hedonic OLS and SHAC models

\begin{tabular}{|c|c|c|}
\hline Variables & OLS & SHAC \\
\hline Intercept & $7.8130 \ddagger(0.0654)$ & $7.3565 \ddagger(0.2682)$ \\
\hline Log(Property area, m2) & $0.1188 \ddagger(0.0024)$ & $0.1200 \ddagger(0.0084)$ \\
\hline Number of bedrooms & $0.4728 \ddagger(0.0185)$ & $0.4688 \ddagger(0.0403)$ \\
\hline Number of bedrooms, squared & $-0.0306 \ddagger(0.0027)$ & $-0.0307 \ddagger(0.0049)$ \\
\hline Tourist town & $0.0757 \ddagger(0.0067)$ & $0.0724 *(0.0377)$ \\
\hline Log(Population gravity index) & $0.0538 \ddagger(0.0029)$ & $0.0507 \ddagger(0.0137)$ \\
\hline Log (Conservation area accessibility) & $0.1026 \ddagger(0.0058)$ & $0.0983 \ddagger(0.0301)$ \\
\hline Log (Distance to BMF, km) & $-0.1123 \ddagger(0.0069)$ & $-0.1049 \ddagger(0.0367)$ \\
\hline Log(Distance to river, $\mathrm{km}$ ) & $-0.0347 \ddagger(0.0040)$ & $-0.0350(0.0239)$ \\
\hline Log(Distance to nearest lake, $\mathrm{km}$ ) & $-0.0383 \ddagger(0.0038)$ & $-0.0373 *(0.0192)$ \\
\hline Monthly average NDVI, 12 months prior to sale & $5.6 \mathrm{E}-05 \ddagger(4.7 \mathrm{E}-06)$ & $5.4 \mathrm{E}-05 \ddagger(1.9 \mathrm{E}-05)$ \\
\hline Average daily flow, GL, 3 months prior to sale & $2.3 \mathrm{E}-02 \ddagger(2.1 \mathrm{E}-03)$ & $2.2 \mathrm{E}-02 \ddagger(6.0 \mathrm{E}-03)$ \\
\hline \multicolumn{3}{|l|}{$X$ (in the flood zone) } \\
\hline $\begin{array}{l}\text { Average daily flow, GL, } 3 \text { months prior to sale, squared } \\
X \text { (in the flood zone) }\end{array}$ & \multicolumn{2}{|c|}{$X$ (in the flood zone) } \\
\hline \multicolumn{2}{|l|}{$X(<50 \mathrm{~km}$ from the flood zone) } & $6.7 \mathrm{E}-03+(3.0 \mathrm{E}-03)$ \\
\hline $\begin{array}{l}\text { Average daily flow, } \mathrm{GL}, 3 \text { months prior to sale, squared } \\
X(<50 \mathrm{~km} \text { from the flood zone) }\end{array}$ & $X(<50 \mathrm{~km}$ from the flood zone) & $-1.6 \mathrm{E}-04+(6.6 \mathrm{E}-05)$ \\
\hline $\begin{array}{l}\text { Average daily flow, GL, } 3 \text { months prior to sale } \\
X(>50 \mathrm{~km} \text { away from the flood zone) }\end{array}$ & $X(>50 \mathrm{~km}$ away from the flood zone) & $-1.5 \mathrm{E}-03(3.3 \mathrm{E}-03)$ \\
\hline \multicolumn{2}{|l|}{$X(>50 \mathrm{~km}$ away from the flood zone) } & $1.3 \mathrm{E}-05$ (7.2E-05) \\
\hline Elevation, m & $1.6 \mathrm{E}-03 \neq(8.1 \mathrm{E}-05)$ & $1.5 \mathrm{E}-03 \ddagger(3.8 \mathrm{E}-04)$ \\
\hline Month of year & $-0.0152 \ddagger(0.0038)$ & $-0.0145 \ddagger(0.0049)$ \\
\hline Month of year squared & $8.0 \mathrm{E}-04 \ddagger(2.8 \mathrm{E}-04)$ & $7.5 \mathrm{E}-04+(3.4 \mathrm{E}-04)$ \\
\hline Trend, years & $0.2499 \ddagger(0.0043)$ & $0.2493 \ddagger(0.0075)$ \\
\hline Trend, years, squared & $-0.0119 \ddagger(0.0003)$ & $-0.0119 \ddagger(0.0006)$ \\
\hline Spatial lag & & $0.0424 \ddagger(0.0057)$ \\
\hline $\mathrm{N}$ & 31706 & 31706 \\
\hline R-squared & 0.4134 & \\
\hline Pseudo R-squared & & 0.4177 \\
\hline Breusch-Pagan test & $239.9 \ddagger$ & \\
\hline
\end{tabular}

Note: standard errors are in parentheses, BMF=Barmah-Millewa Forest

* Significant at $10 \%$ level; † significant at 5\% level; $¥$ significant at $1 \%$ level. 
To test for spatial autocorrelation and to estimate the spatial model, it is necessary to construct a spatial weight matrix. To determine threshold distances and the decay function of the fixed distance spatial weight matrix, we estimated an empirical covariogram of the OLS model residuals and fitted it with the exponential theoretical covariogram (Polyakov et al., 2014). The range parameter of the exponential covariogram is equal to $944 \mathrm{~m}$ suggesting that the threshold distance of spatial correlation of the OLS residuals is $2,832 \mathrm{~m}$. The scale parameter of the exponential covariogram is equal to 0.0504 resulting in a decay function of the weight matrix $w_{i j}=0.0504 *\left(\exp \left(-1 *\left(d_{i j} / 944.0\right)\right)\right)$ where $w_{i j}$ is the weight of the spatial relation between observations $i$ and $j$, and $d$ is the distance between observations $i$ and $j$ in meters.

We used the weight matrix to test the OLS model for autocorrelation (Table 3). The Moran's I statistic indicates that spatial dependencies are present in the dataset. The Lagrange multiplier test (Anselin and Rey, 1991) indicates that both spatial lag and spatial lag dependencies are present, however spatial error dependency is a greater concern, which is confirmed in the robust Lagrange multiplier test (Anselin et al., 1996).

Table 3 Spatial autocorrelation test statistics results of the OLS model

\begin{tabular}{lcc}
\hline Test & Statistics & P-value \\
\hline Spatial correlation in OLS residuals & & \\
$\quad$ Moran I statistic standard deviation & 136.98 & $<0.0001$ \\
$\begin{array}{l}\text { Spatial error dependence } \\
\quad \text { Lagrange multiplier test }\end{array}$ & 18927.04 & $<0.0001$ \\
$\quad$ Robust Lagrange multiplier test & 18423.40 & $<0.0001$ \\
Spatial lag dependence & & \\
$\quad$ Lagrange multiplier test & 592.01 & $<0.0001$ \\
$\quad$ Robust Lagrange multiplier test & 88.37 & $<0.0001$ \\
& & \\
Spatial lag and error dependence (SARMA) & & $<0.0001$ \\
$\quad$ Lagrange multiplier test & 19015.41 & \\
\hline
\end{tabular}

Due to the presence of both spatial lag and spatial error as well as heteroskedasticity, we estimate a spatial model with SHAC standard error (Kelejian and Prucha, 2010). The results of the estimation are presented in Table 2. To assess goodness of fit we used a variance ratio pseudo- $R^{2}$. 
The coefficient for the spatial lag is positive and significant; however it is small in magnitude. The signs of the coefficients in the OLS and spatial SHAC models are consistent with our expectations and the magnitudes of the coefficients are similar. However, the standard errors are greater in the SHAC model, especially for the spatially correlated variables, such as distance based variables and elevation. This is because heteroskedasticity and autocorrelation consistent standard errors are larger. Still, all of the explanatory variables remain statistically significant at least at the $10 \%$ significance level in the spatial SHAC model.

Results of the spatial SHAC model show that the coefficient of the log of property area is significant and positive at the $1 \%$ level. This positive relationship between sales price and property size is expected. The coefficient of the number of bedrooms is also positive and highly significant; however, we found a negative and significant relationship for the squared term of the number of bedrooms, suggesting diminishing returns to the size of the living area of the house. Elevation is positively correlated with sales prices, suggesting that the better the view shed (from increased elevation) the higher the property value.

In terms of neighbourhood effects, the presence of neighbouring tourist towns has a positive effect on sales price. Furthermore the log of PGI, a measure of population and market access, positively influences property values. This confirms our expectation that proximity to, and the size of, populated places drive demand for residential properties. The level of landscape greenness (NDVI) for the 12 months prior to sales is positive and significant suggesting that the greener the landscape the higher the property sales price.

The proximity variable to the BMF is negative and significant, indicating that homeowners pay a premium for a property that is closer to the BMF. The coefficients for proximity to the river and lake are also negative and significant, suggesting a positive benefit of living closer to the river or the lake.

With regards to the impact of in stream flow on property price, we found that in stream flow has significant non-linear effect on sales price. The non-linear effect of in stream flow on sales price translates to positive marginal benefits of increased in stream flows at low in stream flow levels, and negative marginal effects at higher in stream flow levels. The inflection point, where marginal benefit of in stream flow is zero, is around $21 \mathrm{GL} /$ day. The significant interaction terms between in stream flow and flood zone suggest that property prices of houses within the flood zone, or within $50 \mathrm{~km}$ of the flood zone, vary more with flow level than houses that are far away, $>50 \mathrm{~km}$ from the flood zone. 
Seasonal and spatial influences on flow were tested by including interaction terms of flow with distance to the BMF and flow with time of year in the hedonic model but were not found to be significant. Hence, the marginal benefit of flow does not decay with distance to the BMF or vary with seasonal changes.

\section{Marginal implicit prices}

Table 4 shows the marginal implicit prices (MIPs) and elasticities of the statistically significant explanatory variables at the mean property value and mean of each respective explanatory variable. The MIPs and elasticities were calculated using coefficients from the spatial SHAC model. MIP and elasticity for a binary variable was calculated following Halvorsen and Palmquist (1980). Because we found that spatial lag coefficient $\rho$ is statistically significant, MIPs and elasticities were adjusted using the multiplier $1 /(1-\rho)$ to take into account spill-over effects (Kim et al., 2003). Assuming that the property market is in equilibrium, the level of WTP is reflected in the MIP, which is the value of the amenity capitalized in the residential property price. For an average property on 8,465 square meters of land, with 3 bedrooms, and valued at $A \$ 199,000$, an additional bedroom adds around $A \$ 57,700$. Properties near tourist towns on average sell for $A \$ 15,000$ more than properties that do not have a tourist town nearby. For an average house that is $3 \mathrm{~km}$ away from the nearest river, moving $1 \mathrm{~km}$ closer will increase the sales price by around $A \$ 2,400$. 
Table 4 Marginal implicit prices and elasticities of significant variables from the SHAC model

\begin{tabular}{lrc}
\hline Variable & $\begin{array}{c}\text { Marginal implicit price at } \\
\text { the mean of the variable }\end{array}$ & $\begin{array}{c}\text { Elasticity at the mean } \\
\text { of the variable }\end{array}$ \\
\hline Property area, $\mathrm{m} 2$ & 2.95 & 0.13 \\
Number of bedrooms & $57,771.17$ & 0.90 \\
Tourist town & $15,603.79$ & 0.08 \\
Population interaction index & 0.75 & 0.05 \\
Conservation area accessibility index & 13.04 & 0.10 \\
Distance to BMF, km & -289.56 & -0.11 \\
Distance to river, $\mathrm{km}$ & $-2,414.38$ & -0.04 \\
Distance to lake, km & $-1,160.83$ & -0.04 \\
Monthly average NDVI, 12 months prior to sale & 11.18 & 0.29 \\
Average daily flow, GL, 3 months prior to sale X (in the & $2,529.28$ & 0.12 \\
flood zone) & & 0.04 \\
Average daily flow, GL, 3 months prior to sale X (<50 km & 750.61 & \\
from the flood zone) & & 0.26 \\
Elevation, $\mathrm{m}$ & 319.60 & \\
\hline
\end{tabular}

There is also value in proximity to the Barmah-Millewa Forest. For an average property, which is approximately $75 \mathrm{~km}$ away from the BMF, moving $1 \mathrm{~km}$ closer will increase the sales value by $A \$ 290$. The MIP of proximity to the BMF may appear small at the mean of the sample, but for properties that are very close to the BMF, for example, if a house is located $10 \mathrm{~km}$ from BMF, moving $1 \mathrm{~km}$ closer will increase sales price by around $A \$ 2,000$.

The relationship between flow and sales price is significant and non-linear. However, the MIP of flow is highly different between properties within the flood zone, $<50 \mathrm{~km}$ from the flood zone and $>50 \mathrm{~km}$ from the flood zone. At mean flow of $9.6 \mathrm{GL} /$ day, an extra gigaliter $(\mathrm{GL})$ of average daily flow to the BMF adds $A \$ 2,500$ to the sales price of properties within the flood zone and $A \$ 750$ to properties that are $<50 \mathrm{~km}$ away from the flood zone. When average daily flow reaches approximately $21 \mathrm{GL} /$ day, the marginal value of flow becomes zero for all properties, and any further increase in flow has a negative impact on property values. The negative impact is larger for properties within the flood zone than properties that are further away (as shown in Figure 2). 


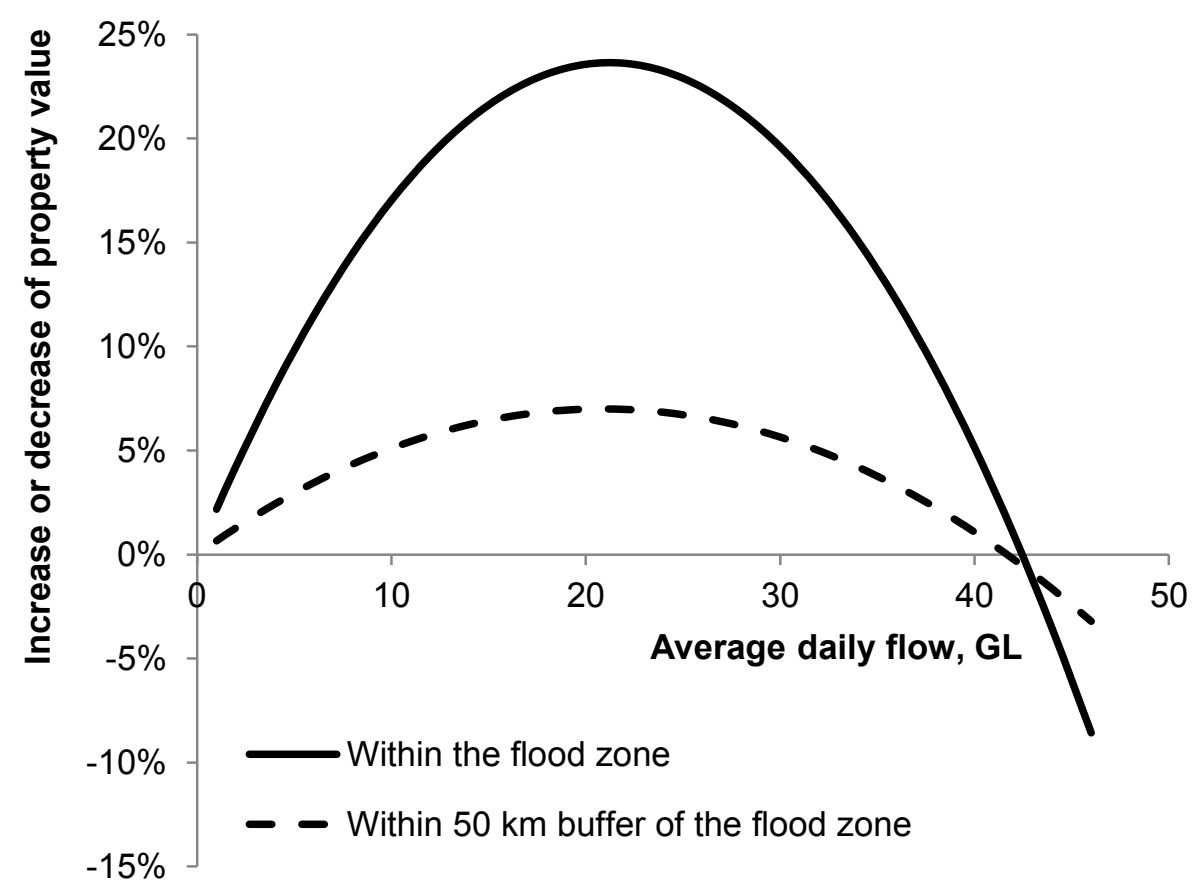

Figure 2 Plot of expected percent change in property price with respect to flow for properties within the flood zone and properties within a $50 \mathrm{~km}$ buffer of the flood zone

\section{Discussion}

The results show that homeowners in the Murray-Darling Basin pay premiums to live closer to the Barmah-Millewa Forest and to the Murray River, and for houses in greener landscapes. These premiums may partially capture the aesthetic values or aesthetic benefits and recreation values homeowners receive from landscapes. Aesthetic values and recreation values are categorized as cultural ecosystem services (Millennium Ecosystem Assessment, 2005; TEEB 2010). These findings support the results of other research that have demonstrated that homeowners are willing to pay premiums to live, near rivers both within the basin (Tapsuwan et al., 2012) and in other markets (Bark et al., 2009).

Beyond these typical proximity and greenness attributes the results also provide evidence that homeowners in our study area have preferences around river flows. The marginal benefit of river flow has not been estimated before in the basin: it provides new information on the aesthetic and recreational benefits of river flow that are capitalized in property prices. The values presented in this paper could be used for future research, such as benefit transfer, or to guide policy decisions relating 
to future water resources planning in particular the sharing of water resources between different users and any associated impacts on in stream flows.

The non-linear relationship between flow and sales price suggests a complex set of preferences around flow. This supports earlier work by Pflüger et al. (2010) who found using survey responses from river users in six southeast New Zealand rivers a concave relationship between preferences and mean river flow. They suggest that "(1) low aesthetic quality at low flows corresponds to exposed banks and channel areas; (2) low aesthetic quality at very high flows corresponds to turbidity and the presence of suspended debris; (3) changes in water colour can over-ride water quantity as a determinate of aesthetic value, if the colour changes are distinct" (Pflüger et al., 2010). Likewise our results suggest that homeowners have preferences for normal flow that is neither for dry period flows nor for high flows. These preferences may be indirect, that is not for flow itself, but linked to the visual disamenity as suggested by Pflüger et al. (2010) or to wider regional economic impacts associated with droughts and floods. They could also be direct with homeowners linking flows and access to recreational sites or flood hazard.

What are the policy implications of these findings? Firstly, low flows are less probable under new management of basin water resources in Basin Plan 2012 (MDBA, 2012) and our research shows homeowners living near BMF value such change. The mechanisms to secure environmental flows are a federal government buyback of agricultural water licences and investment in irrigation infrastructure (Bark et al., 2014). The management of this portfolio of federal environmental water for basin environmental objectives rests with the Commonwealth Environmental Water Office but will be implemented through State water sharing plans (Garrick et al., 2012). Secondly, however, stored environmental water will be released to simulate summer floods, and our results show homeowners will not prefer such flows if they exceed the threshold $21 \mathrm{GL} /$ day. Where our results might influence policy relates to the inflection point in the non-linearity effect of the marginal benefit of river flow. Increasing environmental flows up to this point results in benefits to homeowners and to a suite of ecological benefits linked to increased river flow (CSIRO, 2012). Beyond this point increased flow may still provide incremental ecological benefits but also disbenefits to nearby homeowners. Consequently, when deciding on the optimal environmental water flow to the BMF, State water sharing planners in Victoria and NSW can use this information to maximise and/or trade-off socially desirable aesthetic benefits with ecological benefits. 


\section{Conclusion}

This paper is the first hedonic analysis of the Barmah-Millewa Forest. It provides estimates of the marginal benefit of living in close proximity to the Barmah-Millewa Forest and the first estimate of the marginal benefit of river flow that is capitalized in property prices. The latter estimate is of particular relevance to water sharing reform in the Basin that will result in more flow left in the Basin's rivers and streams. We cannot say whether our estimate represents direct preferences for higher river flows per se or whether nearby homeowners might also value river flow as a proxy for regional economic health and the ecological health of the Basin. Regardless of the underlying preferences the estimate demonstrates in stream values that State water planners who will implement Basin Plan 2012 (Garrick et al., 2012) may, in some catchments with higher populations, take into account.

The ability to make consistent and coherent policy decisions when trade-offs are present requires information both on the ecological response trade-offs (and potential synergies) between different environmental watering regimes and the associated economic trade-offs (and potential synergies). Providing information on these will require tracing changes in environmental flow regimes and floodplain inundation, either directly to economic valuation of incremental flow changes or through ecological response models to value the benefits of enhanced ecosystem outcomes. We are cognisant, but have not explored, that each system has its own temporal, spatial, and jurisdictional dynamics and understanding the interactions between the systems might point to non-linear responses, thresholds and legacy effects that can lead to path dependency and constrain future policy options (e.g. see Liu et al., 2007). With increasing Geographic Information System capabilities and collaboration of multidisciplinary research teams, future studies would be better able to consider these inter-linkages to reflect the complexities of the human-environment interaction.

\section{Acknowledgements}

This research was conducted with funding from the CSIRO Water for Healthy Country Flagship and the Australian Research Council Centre of Excellence for Environmental Decisions.

\section{References}

Anselin, L., 1988. Spatial econometrics: Methods and models. Kluwer Academic Publishers, Dordrecht. Anselin, L., Bera, A. K., Florax, R., Yoon, M. J. 1996. Simple diagnostic tests for spatial dependence. Regional Science and Urban Economics, 26, 77-104. 
Anselin, L., Rey, S. 1991. Properties of tests for spatial dependence in linear regression models. Geographical Analysis, 23, 112-131.

Bark, R.H., Frisvold, G.B., Flessa, K.W. in press. The role of economics in transboundary restoration water management in the Colorado River Delta. Water Resources \& Economics Special Issue on Transboundary water management.

Bark, R.H., Osgood, D.E., Colby, B.G., Katz, G., Stromberg, J. 2009. Habitat preservation and restoration: Do homebuyers have preferences for quality habitat? Ecological Economics, 68, 1465-1475.

Bark, R., Kirby, M., Connor, J., Crossman, N.D. 2014. Water allocation reform to meet environmental uses while sustaining irrigation: a case study of the Murray-Darling Basin, Australia, Water Policy.

Bin, O. 2005. A semiparametric hedonic model for valuing wetlands. Applied Economic Letters, 12, 597-601.

Boxall, P.C., Chan, W.H., McMillan, M.L., 2005. The impact of oil and natural gas facilities on rural residential property values: a spatial hedonic analysis. Resource and Energy Economics, 27, 248-269.

Butsic, V., Netusil, N. R. 2007. Valuing water rights in Douglas County, Oregon, using the hedonic price method. JAWRA Journal of the American Water Resources Association, 43, 622-629.

Daniel, V.E., Florax, R.J.G.M., Rietveld, P. 2009. Flooding risk and housing values: An economic assessment of environmental hazard. Ecological Economics, 69, 355-365.

Dyack, B. E., Rolfe, J., Harvey, J., O'Connell, D., Abel, D. 2007. Valuing recreation in the Murray. CSIRO Water for a Healthy Country Flagship, Canberra.

ESRI 2010. ArcGIS 10. Environmental Systems Research Institute, Redlands CA.

Freeman III, A. M. 1974. On estimating air pollution control benefits from land value studies. Journal of Environmental Economics and Management, 1, 74-83.

Garrick, D., Anderson, G.R.M., Connell, D., Pittock, J. 2014. (Eds.), Federal Rivers: Managing Water in Multi-Layered Political Systems. Edward Elgar, Massachusetts.

Garrick, D., Bark, R.H., Connor, J., Banerjee, O. 2012. Environmental water governance in federal rivers: opportunities and limits of subsidiarity in the River Murray of Australia, Water Policy, 14, 915-936.

Garrick, D., Bark, R. 2011. Comparative perspective on basin governance in the Murray Darling Basin: Insights from the Western U.S., pp 367-384. In: D. Connell and R. Quentin Grafton (Eds.), Basin Futures: Water reform in the Murray-Darling Basin. ANU E Press, Canberra.

Garrick, D., Siebentritt, M., Aylward, B., Bauer, C.J., Purkey, A. 2009. Water markets and freshwater ecosystem services: policy reform and implementation in the Columbia and Murray Darling Basins. Ecological Economics, 69, 366-379. 
Gibbons, S., Mourato, S., Resende, G.M. 2014. The amenity value of English nature: a hedonic price approach. Environmental Resource Economics, 57, 175-196.

Glenn, E.P., Flessa, K.W., Pitt, J. 2013. Restoration potential of the aquatic ecosystems of the Colorado River Delta, Mexico: Introduction to special issue on "Wetlands of the Colorado River Delta", Ecological Engineering, 59, 1-6.

Hanson, T. R., Hatch, L. U., Clonts, H. C. 2002. Reservoir water level impacts on recreation, property, and nonuser values. JAWRA Journal of the American Water Resources Association, 38, 10071018.

Halvorsen, R., Palmquist, R., 1980. The interpretation of dummy variables in semilogarithmic equations. The American Economic Review, 70, 474-475.

Helmers, C., Patnam, M., 2014. Does the rotten child spoil his companion? Spatial peer effects among children in rural India. Quantitative Economics, 5, 67-121.

Kim, C. W., Phipps, T. T., Anselin, L. 2003. Measuring the benefits of air quality improvement: A spatial hedonic approach. Journal of Environmental Economics and Management, 45, 24-39.

Kelejian, H.H., Prucha, I.R. 2010. Specification and estimation of spatial autoregressive models with autoregressive and heteroskedastic disturbances. Journal of Econometrics, 157, 53-67.

King, A. J., Tonkin, Z., Mahoney, J. 2007. Assessing the effectiveness of environmental flows on fish recruitment in Barmah-Millewa Forest. Report to the Murray-Darling Basin Commission (now Murray-Darling Basin Authority). Arthur Rylah Institute for Environmental Research, Department of Sustainability and Environment, Victoria.

Lansford, N. H. J., Jones, L. L. 1995. Recreational and aesthetic value of water using hedonic price analysis. Journal of Agricultural and Resource Economics, 20, 341-355.

Lewis, L.Y., Bohlen, C., Wilson, S. 2008. Dams, dam removal, and river restoration: a hedonic property value. Contemporary Economic Policy, 26, 175-186.

Loomis, J. 2006. Importance of Including Use and Passive Use Values of River and Lake Restoration. Journal of Contemporary Water Research \& Education, 134, 4-8.

Loomis, J., Feldman, M. 2003. Estimating the benefits of maintaining adequate lake levels to homeowners using the hedonic property method. Water Resources Research, 39, 1259.

Liu , J., Dietz, T., Carpenter, S. R., Alberti, M., Folke, C., Moran, E., Pell, A.N., Deadman, P., Kratz, T., Lubchenco, J., Ostrom, E., Ouyang, Z., Provencher, W., Redman, C.L., Schneider, S.H., Taylor, W.W. 2007. Complexity of coupled human and natural systems. Science, 317, 1513-1516.

Maddison, D. 2009. A Spatio-temporal Model of Farmland Values. Journal of Agricultural Economics, 60, 171-189.

Mahan, B.L., Polasky, S., Adams, R.M., 2000. Valuing urban wetlands: a property price approach. Land Economics. 76, 100-113.

Maunsell et al., 1992 
Medellín-Azuara, J., Lund, J.R., Howitt, R.E. 2007. Water supply analysis for restoring the Colorado River Delta, Mexico. Journal of Water Resources Planning and Management, September/October, 462-471

Millennium Ecosystem Assessment. 2005. Ecosystems and human well-being: synthesis. Island Press, Washington, DC.

Murray-Darling Basin Authority. 2004. The Barmah-Millewa Forests and Barmah-Millewa Forum. URL http://www2.mdbc.gov.au/nrm/water_issues/flood_plain_management/barmahmillewa _floodplain.html [April 2012].

Murray-Darling Basin Commission 2005. The Living Murray Foundation Report on the significant ecological assets targeted in the First Step Decision. MDBC Publication No. 09/05, Canberra.

Murray-Darling Basin Authority. 2012. Assessment of environmental water requirements for the proposed Basin Plan: Barmah-Millewa Forest. Murray-Darling Basin Authority. URL http://www.mdba.gov.au/sites/default/files/archived/proposed/EWR_proposed_BP_Barma h_Millewa.pdf [March 2013].

Murray-Darling Basin Authority. (2013). River Murray Flood Mapping (1956 flood). Retrieved September 2014, from Murray-Darling Basin http://www.mdba.gov.au/kid/files/River Murray Flood Mapping.zip [September 2013].

Netusil, N. R., Summers, M. T. 2009. Valuing instream flows using the hedonic price method. Water Resources Research, 45, W11429.

Olmstead, S. M. 2010. The Economics of Managing Scarce Water Resources. Review of Environmental Economics and Policy 4, 179-198.

Pandit, R., Polyakov, M., Tapsuwan, S., Moran, T., 2013. The effect of street trees on property value in Perth, Western Australia. Landscape and Urban Planning, 110, 134-142.

Pflüger, Y., Rackham, A., Larned, S. 2010. The aesthetic value of river flows: an assessment of flow preferences for large and small rivers. Landscape and Urban Planning, 95, 68-78.

Piras, G., 2010. sphet: Spatial Models with Heteroskedastic Innovations in R. Journal of Statistical Software 35, 1-21.

Polyakov, M., Majumdar, I., Teeter, L., 2008. Spatial and temporal analysis of the anthropogenic effects on local diversity of forest trees. Forest Ecology and Management, 255, 1379-1387.

Polyakov, M., Pannell, D.J., Pandit, R., Tapsuwan, S., Park, G., 2015. Capitalized amenity value of native vegetation in a multifunctional rural landscape. American Journal of Agricultural Economics. doi: 10.1093/ajae/aau053

Powe, N. A., Garrod, G. D., Brunsdon, C. F., Willis, K. G. 1997. Using a geographic information system to estimate an hedonic price model of the benefits of woodland access. Forestry, 70, 139-149.

Provencher, B., Sarakinos, H., Meyer, T. 2008. Does small dam removal affect local property values? An empirical analysis. Contemporary Economic Policy, 26, 187-197. 
Rambaldi, A.N., Fletcher, C.S., Collins, K., McAllister, R.R.J. 2013. Housing Shadow Prices in an Inundation prone Suburb. Urban Studies, 50, 1889-1905.

Ramsar Convention 1971. The Convention on Wetlands of International Importance, Especially as Waterfowl Habitat. Ramsar UN Treaty Series No. 14583.

Reserve Bank of Australia. 2011. Consumer price index - G2. Reserve Bank of Australia. URL http://www.rba.gov.au/statistics/tables/\#prices_inflation [June 2012].

Rigby, D., Alcon, F., Burton, M. 2010. Supply uncertainty and the economic value of irrigation water. European Review of Agricultural Economics, 37, 97-117.

Rosen, S. 1974. Hedonic prices and implicit markets: product differentiation in pure competition. Journal of Political Economy, 82, 34-55.

Stone, A. 1992. Contingent valuation of the Barmah wetlands, Victoria. In: Lockwood, M., Lacy, T. D. (Eds.), Valuing Natural Areas: Applications and Problems of the Contingent Valuation Method. Charles Sturt University, Johnstone Centre of Parks, Recreation and Heritage, Albury.

Tapsuwan, S., Ingram, G., Burton, M., Brennan, D. 2009. Capitalized amenity value of urban wetlands: a hedonic property price approach to urban wetlands in Perth, Western Australia. Australian Journal of Agricultural and Resource Economics, 53, 527-545.

Tapsuwan, S., Hatton-Macdonald, D., King, D., Poudyal, N. 2012. A combined site proximity and recreation index approach to value natural amenities: an example from a natural resource management region of Murray-Darling Basin. Journal of Environmental Management, 94, 6977.

Taylor, L.O. 2008. Theoretical Foundations and Empirical Developments in Hedonic Modeling, . In: A. Baranzini, et al. (Eds.), Hedonic Methods in Housing Market Economics. Springer, New York.

TEEB. 2010. The Economics of Ecosystems and Biodiversity: Ecological and Economic Foundations. Edited by Pushpam Kumar. Earthscan, London.

Wei, S., Yang, H., Song, J., Abbaspour, K. C., Xu, Z. 2012. System dynamics simulation model for assessing socio-economic impacts of different levels of environmental flow allocation in the Weihe River Basin, China. European Journal of Operational Research, 221, 248-262. 